\title{
The Analysis of Aeromagnetic Data overWaseand It Adjoining Area
}

\author{
DahiruDahuwa $^{1}$, Yusuf Abubakar Sanusi ${ }^{2}$, Emmanuel Emeka Udensi ${ }^{3}$, \\ Musa Momoh ${ }^{4}$ \\ Physics Department College of Education PMB 044, AzareBauchi State Nigeria ${ }^{1}$ \\ Physics Department UsmanDanfodio University Sokoto, Sokoto State Nigeria ${ }^{2}$ \\ Department of geophysics Federal University of Technology Minna, Niger State Nigeria ${ }^{3}$ \\ Physics Department UsmanDanfodio University Sokoto, Sokoto State Nigeria ${ }^{4}$
}

\begin{abstract}
Aeromagnetic data over Wase and its adjoining areas were obtained and analysed for assessing the mineral potential of the area. The data were digitized andanalysed. The TMI map of the area revealed that the area is magnetically heterogeneous. Areas of very strong magnetic values (32760nT to 32860nT) may likely contain outcrops of crystalline igneous or metamorphic rockswhereas residual magnetic intensity values ranged from $-130 \mathrm{nT}$ to 67nT.The polar plots (i.e. rose diagram) orientations direction of subsurface lineaments trending predominantly along $N E-S W, W N W-E S E$ and NNE-SSW direction with minor trends along NW-SE and N-S directions. Comparison between these lineaments and the surface lineaments suggested that the majority of surface lineaments were structurally controlled.
\end{abstract}

\section{Introduction}

The historical development of geophysics has been motivated by two factors. One of these is the research curiosity of humankind related to Planet Earth and its several components, its events and its problems. The second one is economical usage of Earth resources (ore deposits, petroleum, water resources, etc.) and Earth-related hazards such as earthquakes, volcanoes, tsunamis, tides, and floods. The magnetic method is one of the best geophysical techniques used for determining depth to magnetic source bodies (and possibly sediment thickness) and delineating subsurface structures. Large-scale aeromagnetic surveys have been used to locate faults, shear zones and fractures. Such zones may serve as potential hosts for a variety of minerals and may be used as guidance for exploration of the epigenetic, stress-related mineralization in the surrounding rocks (Paterson and Reeves, 1985). Sediment thickness required for hydrocarbons (oil and/gas) to form or be generated varies from place to place. The minimum sediment thickness required for producing oil usually varies from $2 \mathrm{~km}$ to $4 \mathrm{~km}$, compared to $3 \mathrm{~km}$ to $7 \mathrm{~km}$ for gas production/formation (Dow, 1978; Cornford, 1990; Gluyas and Swarbrick, 2005).

Aeromagnetic maps usually reflect variations in the earth's magnetic field resulting from the underlying rocks' magnetic properties (e.g. magnetic susceptibilities). Sedimentary rocks have the lowest magnetic susceptibility, whereas metamorphic and acidic igneous rocks intermediate and basic igneous rocks have the highest magnetic susceptibility (Keareyet al., 2002). The largest proportion of a magnetic signal or anomaly is thus generated at crystalline (igneous or metamorphic) basement level (GETECH, 2007). Magnetic anomalies are caused by magnetic minerals contained in rocks; such anomalies are usually caused by underlying basement (igneous and/or metamorphic) rocks or by igneous features such as intrusive plugs, dykes, sills, lava flows and volcanic centers when magnetic anomalies are observed over sedimentary terrain (Gunn, 1997). Nevertheless, high sensitivity measurements could also be associated with cultural iron contamination and antigenic alterations in sedimentary rocks, possibly caused by hydrocarbon migration (Costanzo-Alvarez et al., 2000; Aldanaet al., 2003).Several articles have been published on the Nigerian basement complex's structural and tectonic framework, based on interpreting aeromagnetic data (Ajakaiye $e t$ al., 1986; Olasehindeet al., 1990). Ajakaiyeet al., (1986) studied the Benue Trough's tectonic framework and that of parts of the adjoining Nigerian basement complex using aeromagnetic maps, delineating NE-SW and ENE-WSW directions as being the dominant aeromagnetic lineament trends. They stated that these aeromagnetic lineaments depicted a possible continental continuation of the four Atlantic fracture zones (St Paul's, Romanche, Chain and Charcot) abutting the West African coast into the Nigerian basement complex. According to Olasehindeet al. (1990), interpreting aeromagnetic data over central Nigeria's basement complex has shown that the Nigerian basement complex's structural and tectonic framework comprises NE-SW and NW-SE lineaments superimposed over a dominant N-S trend. Overall NE-SW aeromagnetic lineaments of the Benue Trough and Atlantic fracture zones apparently signified an ancient zone of weakness in the Nigerian basement complex. 


\section{Location Of The Study Area}

This study is situated in northern Nigeria Basement Complex (Fig.1.1). The area includes parts of Bauchi and Plateau states. These parts include:Maijuju, TafawaBalwa, Wase, and Pankshin.The area has a balance of geographical features as well as climatic conditions. The entire western and northern parts are generally mountainous and rocky. This is as a result of the closeness to the Jos Plateau.

The area is an agricultural area. Its vast fertile soil is an added advantage for agricultural products, which include maize, rice, millet, groundnut and guinea corn. Irrigation farming is practiced and supported by the use of dams, cattle and other livestock which are reared in the area. Investors are encouraged by the government of the state to seek sufficient expanse of land for agricultural development. Agro-industries are also encouraged.

1 The Basemen Complex
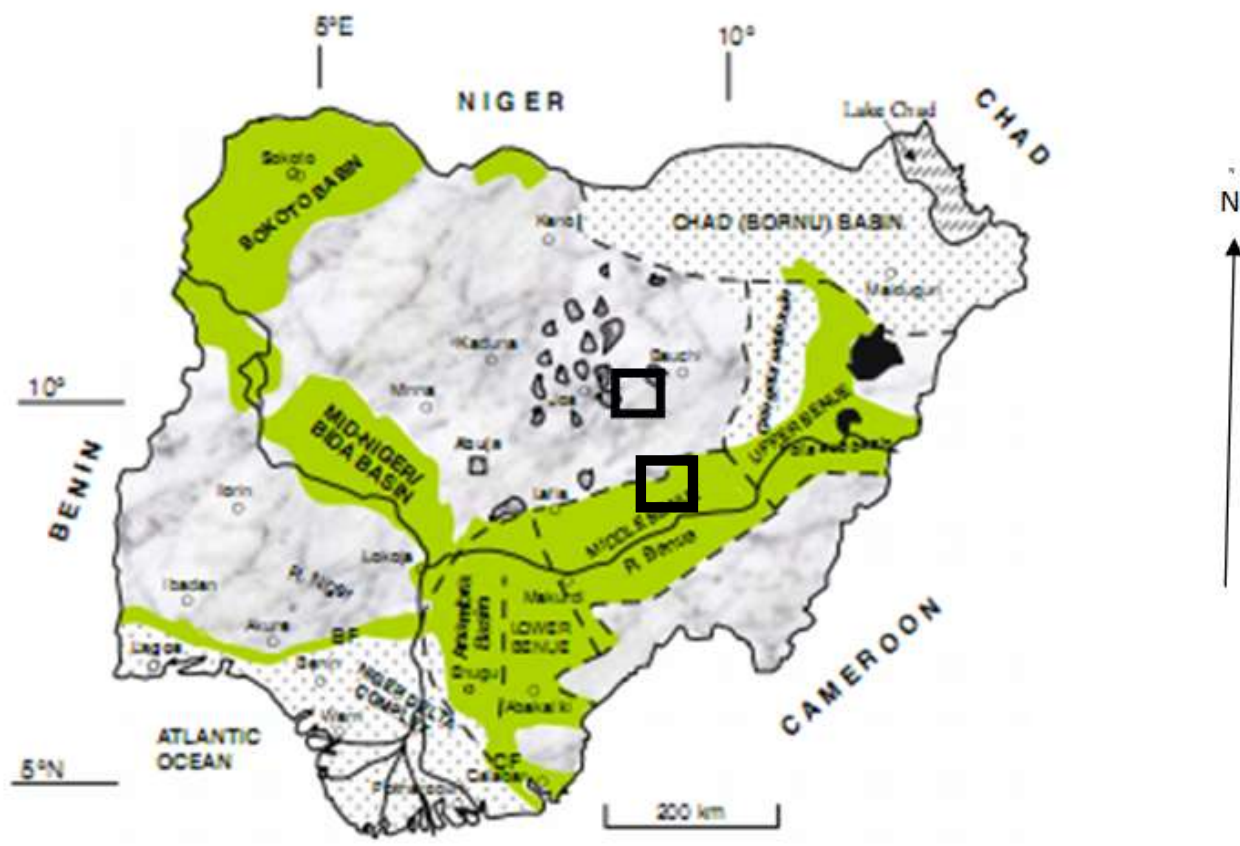

Legend
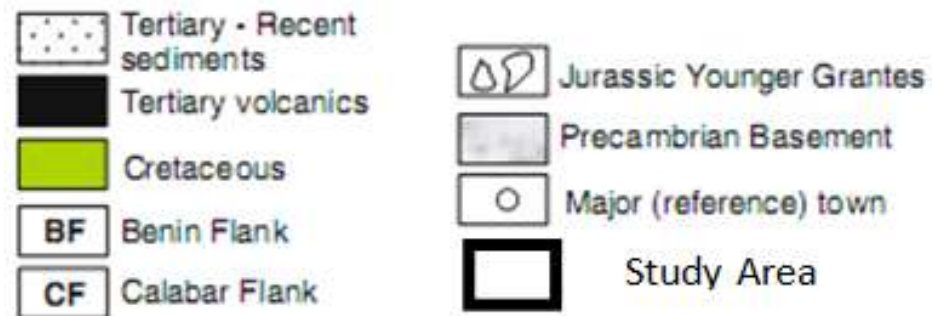

Fig. 1 Location Map of the Study Area Modified After Geological Sketch Map of Nigeria Showing the Major Geological Components

\section{Geology Of The Study Area}

The study area is situated around the Nigerian Basement complex comprising of crystalline rock. Oyawoye (1964) reported that the area consist of gneiss-migmatites, and the older granite Jacobson et al. (1963) also reported that the rock found within the study area comprises of migmatites, granite - gniesses and older granite. This group of rock is believed to be as a result of remobilization during the pan- Africa.

In Nigeria, pan African Granite were named the older Granite (Falconer,1911) to distinguish them from the Mesozoic tin bering volcanic or Granite ring complexes of Jos plateau, which he named the younger granites.According to Ajakaiye (1974), the older granite isconsidered to be of replacement and intrusive origin. The younger Granite occurs largely as distinct pluton often batholitic size ranging in composition from quatrtz hypersthenes diorite through leucocratic granites,porphyriticbiotitegranite,granodiorate and pegmatite. The older granite is seen to occur most in the study area.The area lies generally at an altitude of about $600 \mathrm{~m}$ above sea level, being part of the central Nigeria highlands and Jos Plateau complex. However, two broad relief zones can be identified, as follows:a) A western high land area of hill ranges, including the northern edges of the Jos Plateau complex. This is part of the crystalline rock area in central northern Nigeria. The hill ranges are developed "on 
basement complex rocks, in an area which is also characterized by extensive " plateau surfaces and volcanic extrusions." The base of the hill ranges is generally at the $600 \mathrm{~m}$ level, while peaks rise to $700.6 \mathrm{~m}$ on the hills, and $729.3 \mathrm{~m}$ on the Bunsil hills.b) A central high plain lies within the undifferentiated basement complex with older granites (out-crops) and younger granite out-crops.

The crystalline basement, whose topography is believed to be irregular, is exposed in a number of locations in the region. Intruded into the basement is a series of basic, intermediate and acid plutonic rocks referred to as the older granites. Notable outcrops of the older granites include the small inliers of biotite granites which are found around the area. The uplifted basement rocks in the north-western part of the area were also intruded by acrogenic acid ring complexes, the Younger Granites. The Cretaceous sediments in the area are thought to be compressionally folded in a non-organic shield environment, and the folding took place mainly along ENE-WSW axes. Numerous faults have also been reported in the region. These faults show variable trends but the dominant direction lies between north-north-east and east-north-east.

In the study area, the pre-Cambrian to lower Paleozoic basement gneisses and schist were overlain by alternating shale, siltstones, clay stones and sandstones. The sandstones consist of slightly cemented fine coarse grained sandstone and siltstones with interblended thin beds of carbonaceous shale and clays. The study area is underlain by the basement complex rocks, younger granites and Cretaceous Middle Benue trough's sedimentary rocks. The basement complex rocks in the area are grouped into two, namely migmatite-gneiss and older granites. The older granites consist mainly of granites, diorites and dolerites. Both the migmatites and gneisses were deformed and intruded by the older granites. The study area covers an estimated area of about $18150 \mathrm{Km}^{2}$ between latitudes $9^{0} 00^{1}$ to $10^{0} 00^{1} \mathrm{~N}$ and longitudes $9^{0} 00^{1}$ to $10^{0} 00^{1}$ E. The geologic map of the study area is shown in Figure 2.

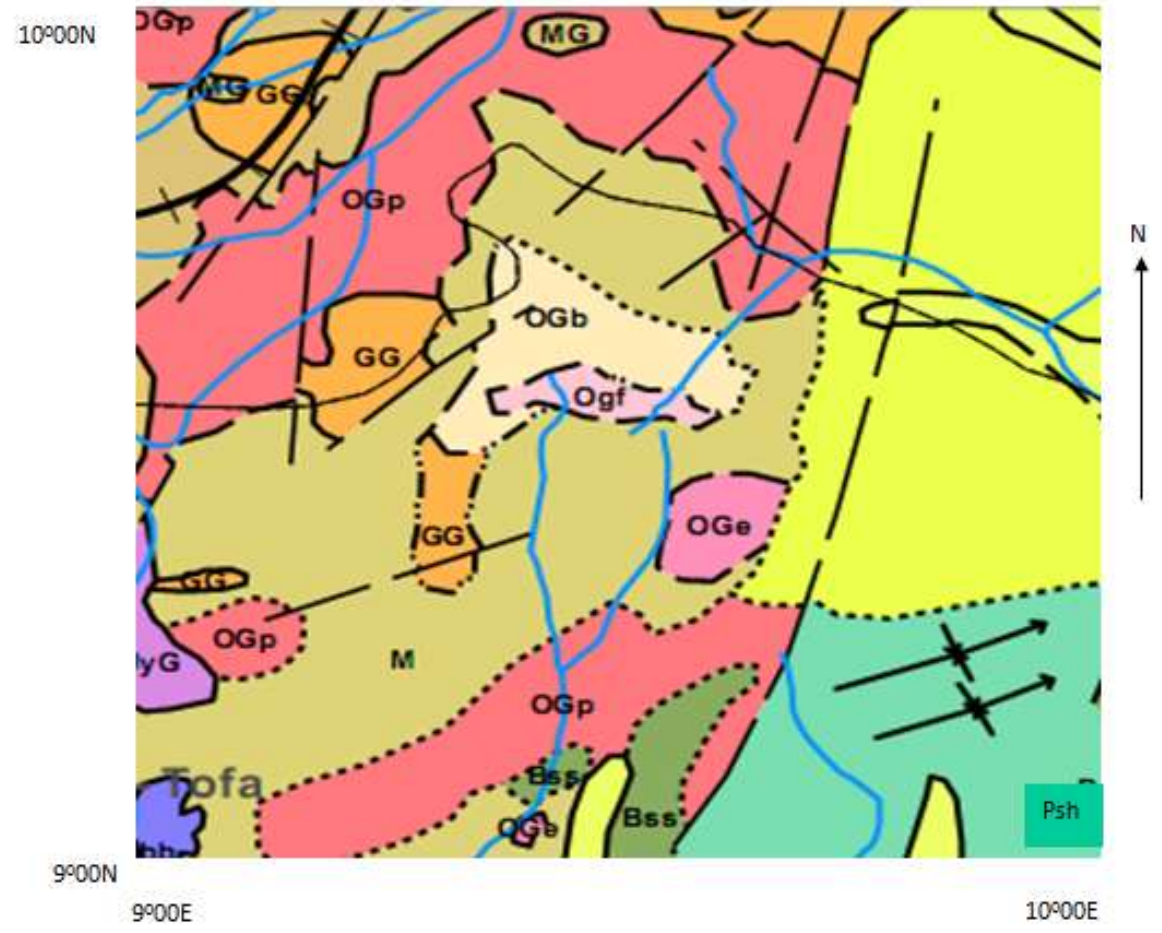




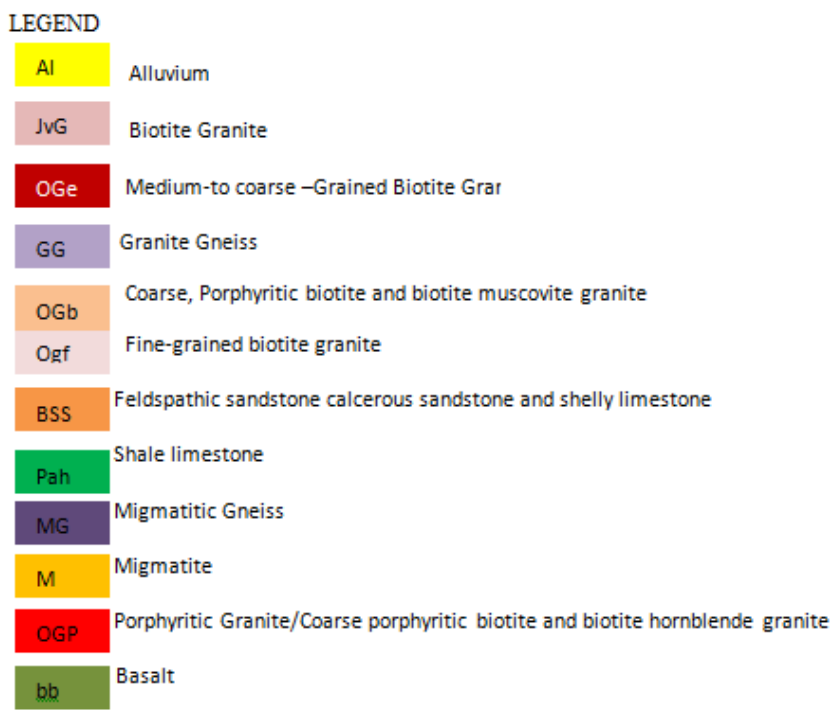

Fig.2Geologic map of the study Area

\section{Material And Methods}

The magnetic data were collected at a nominal flight altitude of $154.2 \mathrm{~m}$ along approximately N-S flight line which is nearly perpendicular to the assumed geologic strike of the area and spaced $2 \mathrm{~km}$ apart. The study area covers four $\frac{1}{2}^{0} \times \frac{1}{2}^{0}$ aeromagnetic maps published by the geological survey of Nigeria (GSN). The maps, which were numbered and named sheets 169, 170, 190, and 191 (Maijuju, TafawaBalewa, Pankshin and Wase respectively) as shown in Figure 3 on a scale of 1:100,000. The total magnetic field intensity values presented in the maps were reduced by $25,000 \mathrm{nT}$. Therefore $25,000 \mathrm{nT}$ were added to the contour values to obtain the actual total magnetic field intensity values.
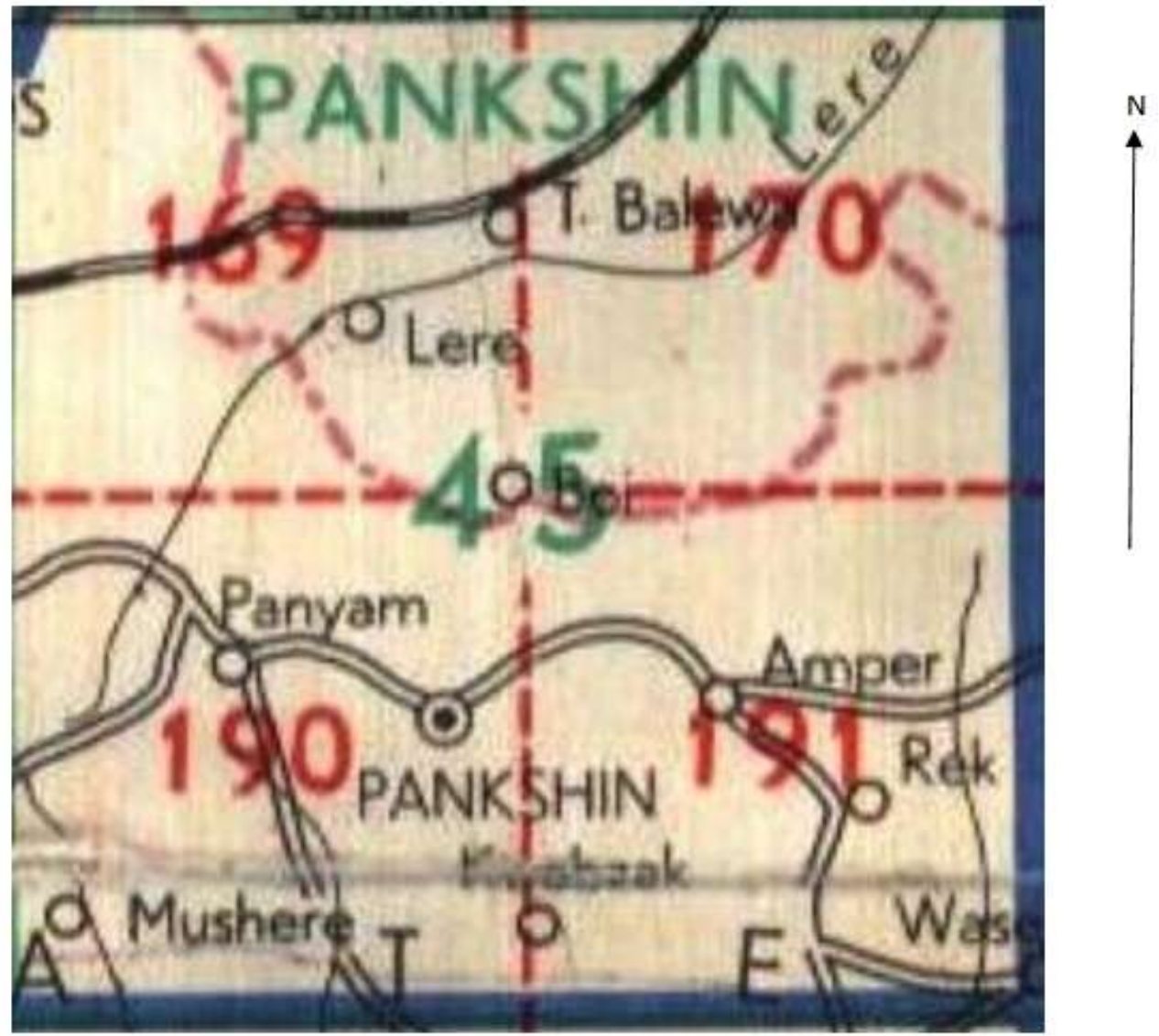

Fig.3:Sheet Map of the Study Area 


\section{Production of Total Magnetic Intensity, TMI Map}

The four aeromagnetic sheets covering the study area were manually digitized at a regular grid spacing $3 \mathrm{~km}$ to recover TMI values. The gridded data were then digitally merged to obtained a composite data set of $37 \mathrm{x} 37$ grid values. The grid interval was found to be adequate for analyzing crustal magnetic anomalies (Udensiet al., 2003) The digitized TMI values were imported into the Surfer 8 and Oasis montajsoftwares and gridded, using the minimum Curvature method and subsequently colour shaded to produce contour colour aggregate of TMI map. Estimate residual values were used to produce contour and colour shaded maps as earlier described.

\section{Qualitative Interpretation}

\section{Results And Discussion}

The colour shaded TMI map Presented in Figure 4, the variation of the TMI values over the study area. The red and pink portions represent areas associated with strong positive anomalies, suggesting higher concentration of magnetic materials. (e.g. magnetite).such areas cover almost the entire NE part of the study area, and the lower parts of the SE and SW parts of the study area. The TMI values associated with these green vary from $32896 \mathrm{nTto}$ 32942nT.Similarly, areas with broad magnetic lows, interpreted as areas of low magnetic concentration, and therefore lower susceptibility were represented by blue colour. Such areas cover almost the entire NE part of the study area. Whereas the pale green and yellow colours represent areas of intermediate magnetic field intensity value between $32893 \mathrm{nT}-32892 \mathrm{nT}$, The magnetic anomaly of magnitude from $32760.0 \mathrm{nT}$ to $32860.0 \mathrm{nTappears}$ to be very dominant and may likely contain outcrops of crystalline igneous or metamorphic rocks, deep seated volcanic rocks or even crustal boundaries' to be conspicuous in the west, northwest, southwest, south and north-eastern parts of the study area. Closely followed by these in spread are those anomalies ranging between 32700nT and 32800nT in magnitude. These are only prominent at the central part of the study area with little traces of it in the northeast, southwest and northwest. Found almost in small quantity are anomalies of very high magnetic intensity value between $32900 \mathrm{nT}$ and 33000nT which are observed the north and south-eastern parts of the study area. Also found in small quantity in the area are the anomalies between 32600nT and 32700nT noticed in the southeast and northeast of the area. Summarily, the TMI map of the area revealed that the area is magnetically heterogeneous. Areas of very strong magnetic values (32760nT to $32860 \mathrm{nT}$ ) may likely contain outcrops of crystalline igneous or metamorphic rocks

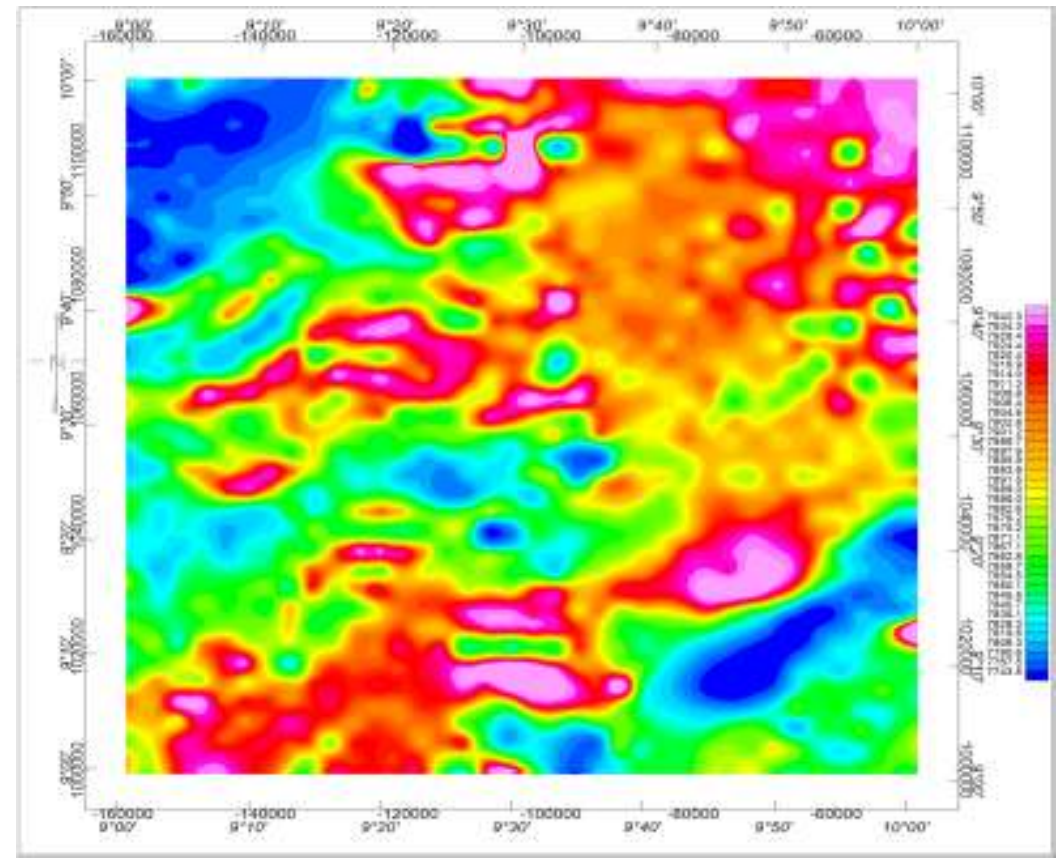

Fig. 4: Total magnetic field intensity (TMI). To obtain the total TMI value, 25,000 nT should be adde

This involves the visual inspection of magnetic maps and inferring geologic information from the observed features, which is useful in preliminary interpretation of magnetic data. Areas of high magnetic value indicate association with high concentration of magnetic minerals (e.g. magnetite). Similarly, areas with broad magnetic lows are likely to be associated with low magnetic concentration, and therefore lower susceptibility. An aeromagnetic survey measures variations in the susceptibility contrast of basement rocks. Interpretation is how the variation in this susceptibility affects the overlying sedimentary section.Prominent Local variations occurring where the basement complex is close to the surface and where concentration of ferromagnetic minerals exists. Thus, the primary applications of the magnetic method are in mapping the basement and locating ferromagnetic ore deposits. 
Visual inspection of total aeromagnetic intensity contour map and the residual aeromagnetic intensity contour map of the study area revealed variations in magnetic field intensity throughout the area. Magnetic field intensity usually increases from the south towards the northern part of the area; such variation is a function of the rock types. The southern part of the area forms part of the Middle Benue Trough which is underlain by Cretaceous sedimentary rocks (Awgu shale and Lafia formation) and thus exhibited predominantly low (highly negative) magnetic intensity, whereas the Pre-Cambrian basement rocks (migmatites, gneisses and older granites) and Jurassic younger granites occupied the northern portion of the area and hence had high (positive) magnetic intensity. The magnetic anomaly contours in the southern portion were smooth and characterized by highly negative, long wavelength, magnetic contour anomalies having E-W and NE-SW direction, which arethe predominant trends in the Benue Trough,(Ajakaiyeet al., 1986) while the magnetic anomaly contours in the northern portion had complex, positive, short wavelength, magnetic anomaly variations trending NE-SW and NW-SE.The NW-SE trend was identified as the minor structural trend on the Benue Trough (Onyedimetal., 2009)

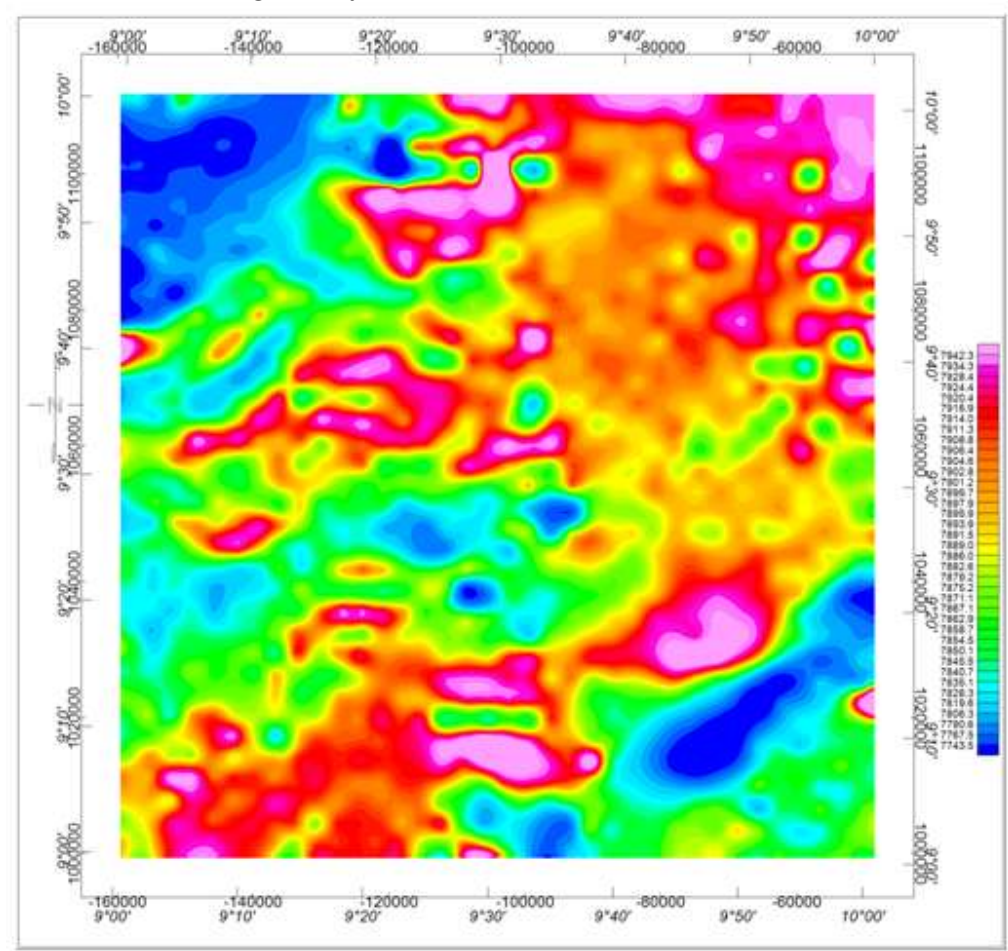

Fig. 5 Residual map of the study area

Furthermore, localized, well-defined, high magnetic anomalies could be observed around the western and west-central portions of the aeromagnetic maps of the study area. Total magnetic intensity values in the aforementioned areas varied from 32960nT to 33020nT, whereas residual magnetic intensity values ranged from -130 $\mathrm{nT}$ to $67 \mathrm{nT}$ (figure 5). Iron ore is being mined by unskilled miners in the area; it could thus be inferred that the localized and well defined high magnetic anomalies may have been associated with the presence of iron ore (having high magnetite to hematite ratio) or other metalliferous mineral deposits within the basement rocks in the area. 


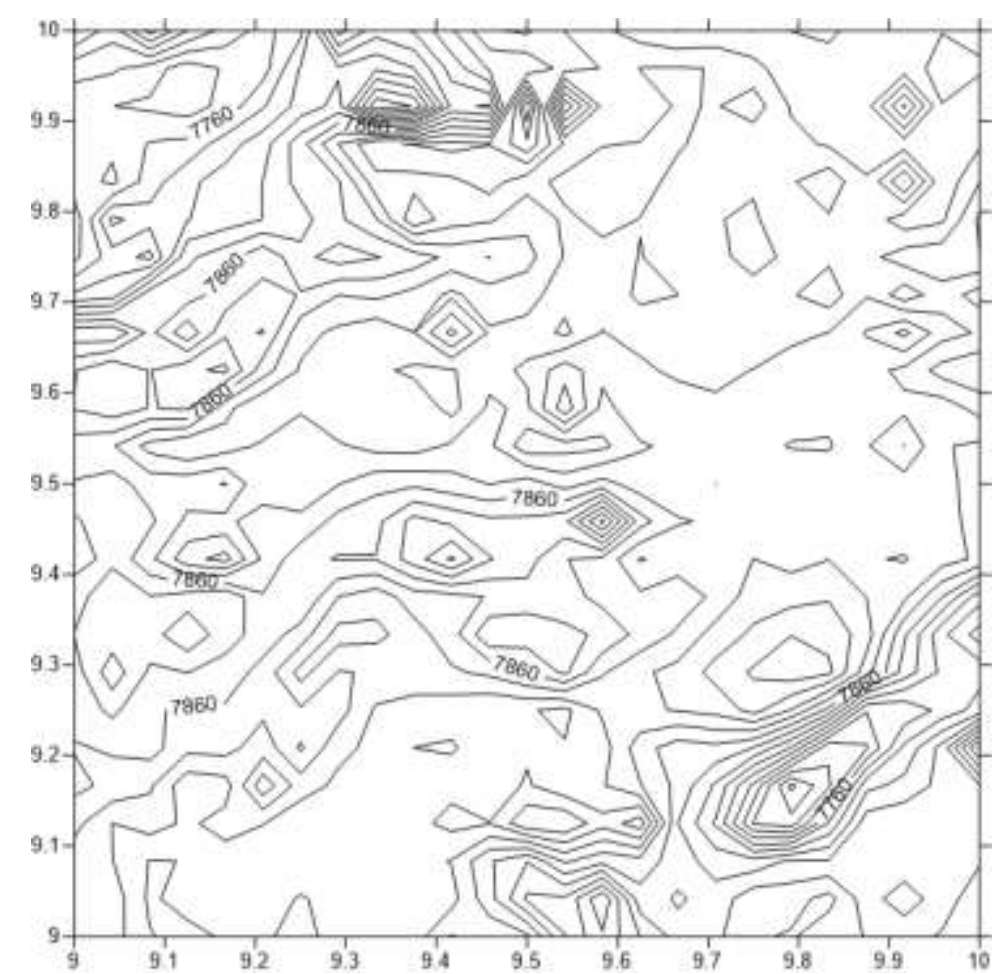

Fig. 6: Total magnetic intensitycontour map of the study area.To obtain the total TMI values, 25,000 nT should be

\section{Superposition of TMI Map on Geologic Map}

added.

The superposition of TMI Map on geologic map Figure 7 shows that most of the magnetic intensity values correlate with the geological features on the geologic map Figure 4. High magnetic intensity at the South-eastern correlates with the Granites Gneisses and Magnetites which are associated with high magnetization. Also the low magnetization at North-eastern correlates with location of MigmatitesGneisses which is known with high magnetization. This may be due to some intrusions of boitite granite, Granite Gneiss and Gabbros which are associated with high magnetization.

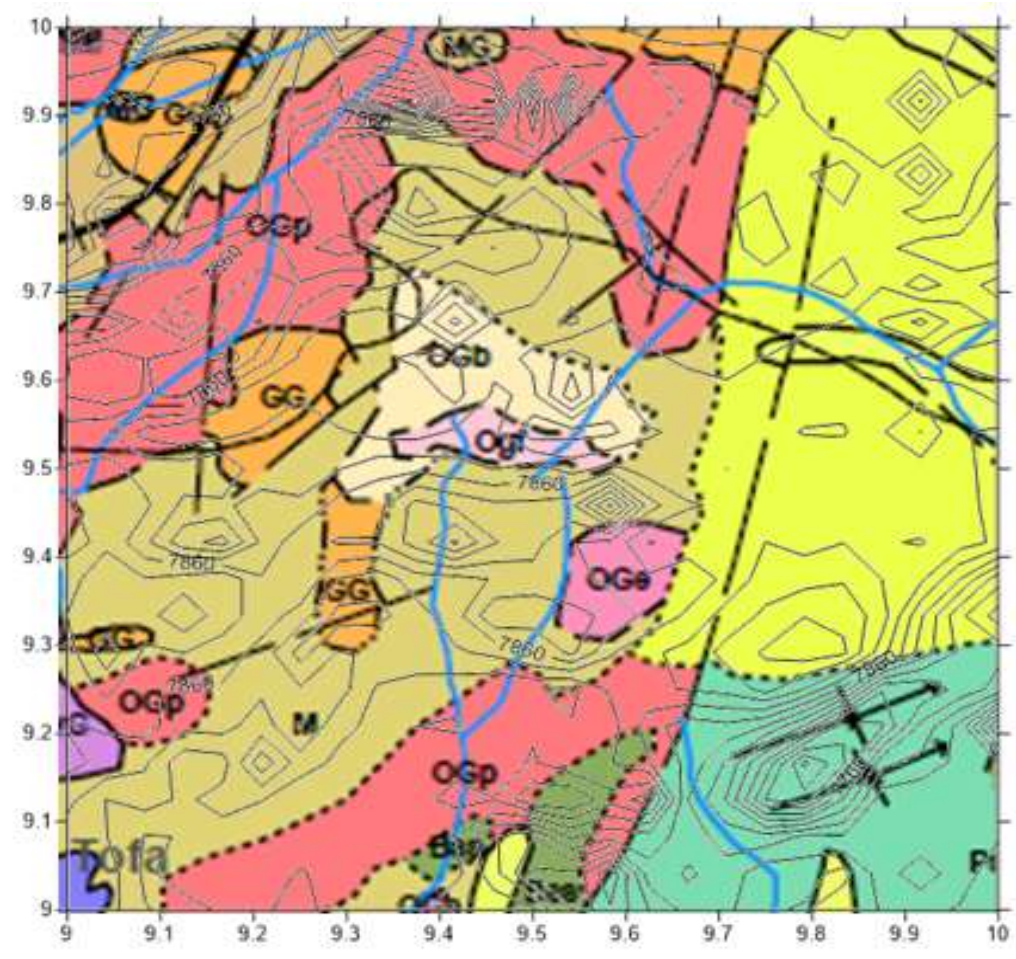




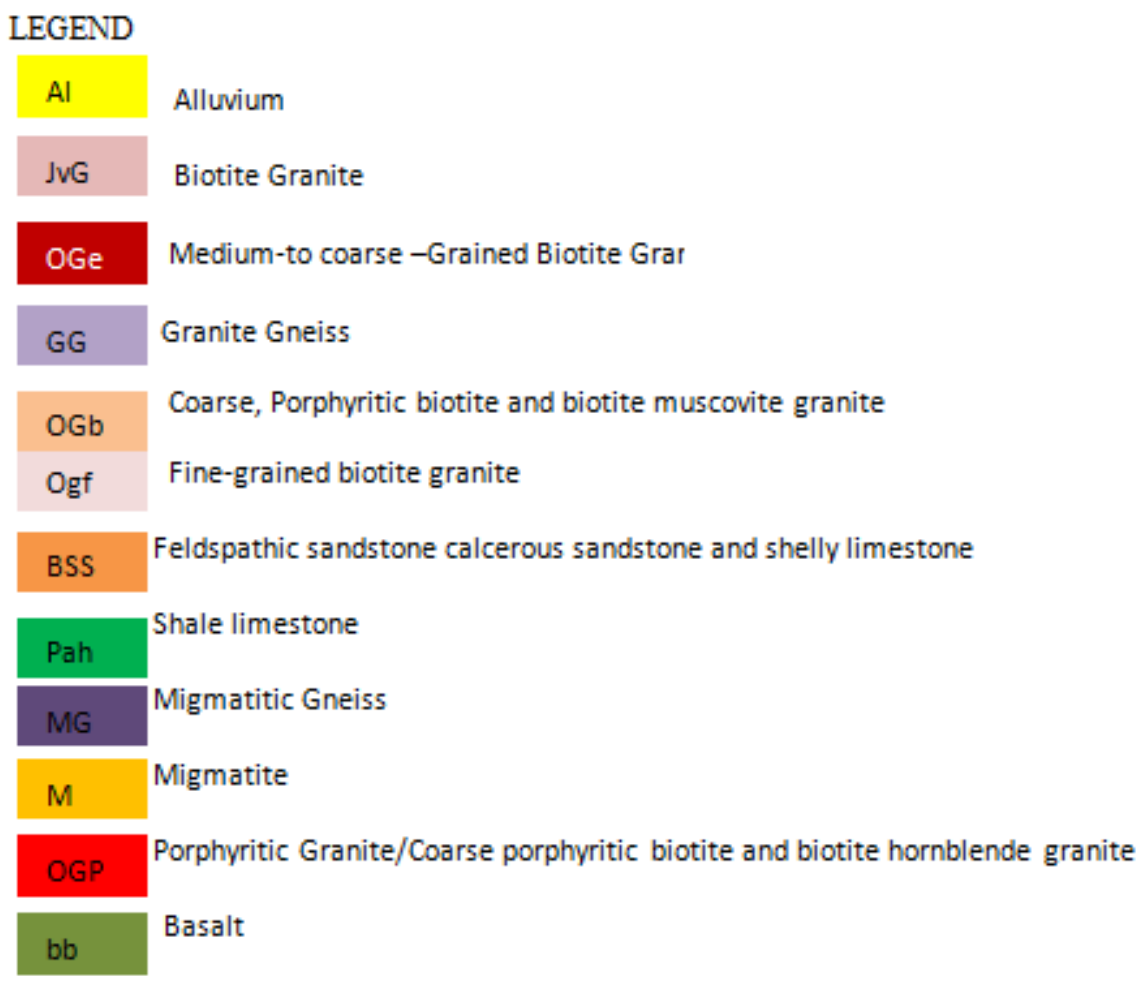

Fig.7: Superposition of TMI Map on Geologic MapPolar Plots (Rose Diagrams)

To quantitatively analyse the trends of the structural lineaments of a study area(Fig.8), arose diagram (i.e. polar plot) was employed, using grapher (version 8.0) software. As can be seen from the plot the lineaments are oriented along E-W, NE-SW, WNW - ESE, NW - SE, and ENE -WSW in decreasing order of predominance. The major trends are E-W and NE-SW while the minor trends are WNW - ESE, NW - SE and ENE - WSW, (Figs. 9). Almost all of the trends were earlier delineated except SSW and SSE which indicated that they reflect hitherto un mapping structures in the study area. The NE - SW and ENE -WSW trends correlate with the general trend of the Benue trough (Ajakaiyeet al., 1983) and the WNW - ESE trends correlates with the Yola arm of the upper Benue trough. (Anuduet al., 2014)

However to infer structural control of the surface lineaments by the subsurface (magnetic) lineaments, the rose diagram of the surface lineaments was plotted. The result shows that the surface lineaments were oriented along NE-SW, WNW-ESE, WNE-SSW, NW-SE, N-S in decreasing order of predominance. Among these trends the NESW, WNW- ESE, and the NNE-SSW were the major trends while the NW-SE and N-S were the minor trends. Comparison between the subsurface (magnetic) and the surface (geologic) lineaments trends shows that the NE - SW, WNW - ESE and the NW -SE are common trends between them, thereby ,suggesting that these surface trends were structurally controlled by the subsurface lineaments. However, the E-W and ENE- WSW surface trends were not reflected among the subsurface lineaments which suggested that these surface lineaments were devoid by magnetic lineaments and were not structurally controlled. It may be plausible to suggest that they were developed in response to the stress associated with the development of the surface lineaments. 


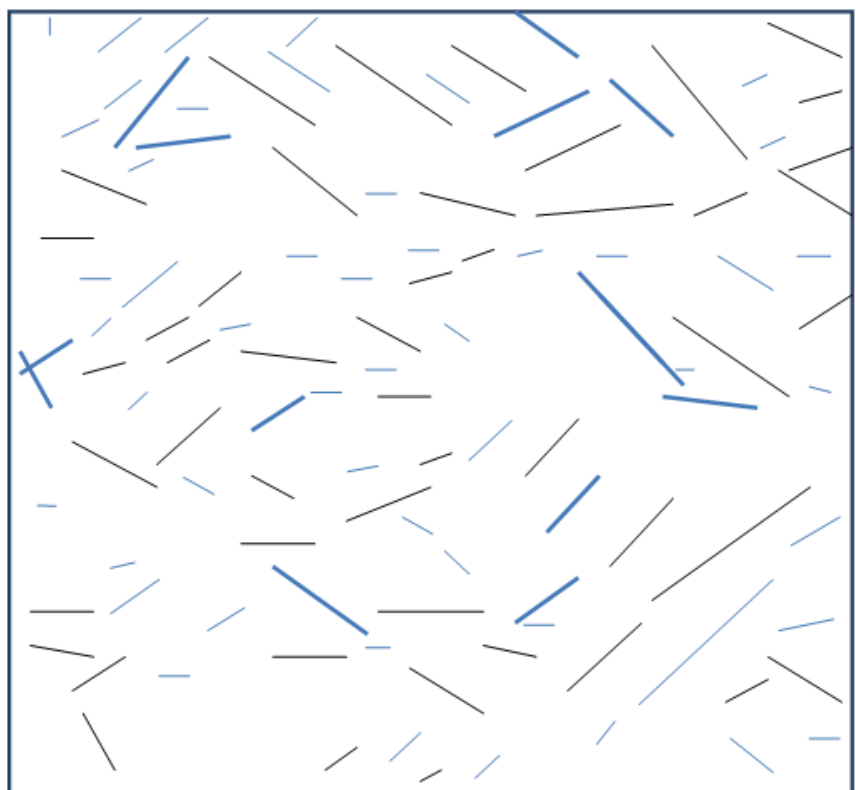

Fig.8: Magnetic Lineament Map of the study Area

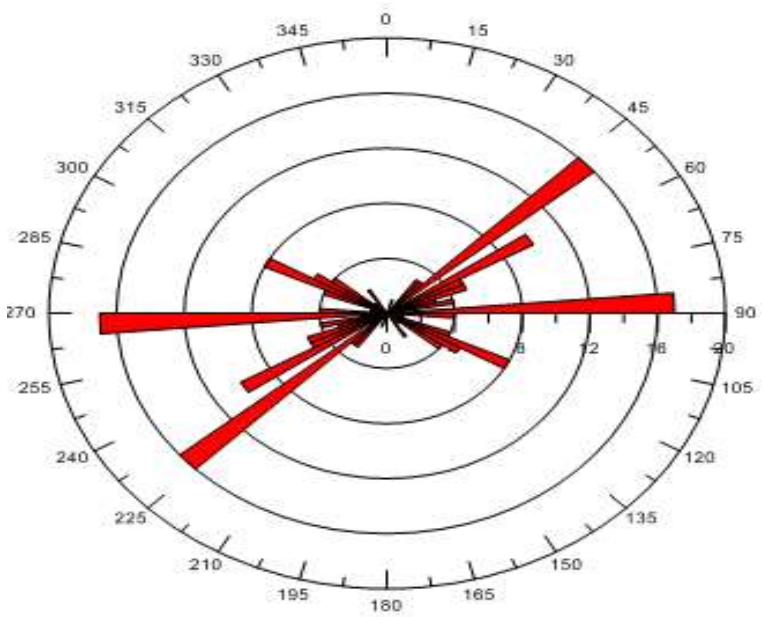

Aeromagnetic Lineament Rose diagram for the study Area

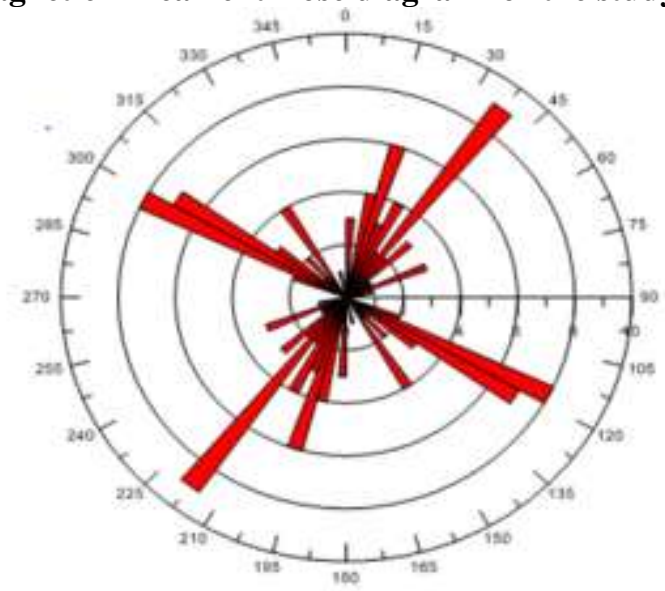

Surface Lineament Rose diagram for the study Area

Figs.9. Frequency Rose diagram for both Aeromagnetic and Surface lineament of the study Area. 


\section{Conclusions}

A total aeromagnetic intensity contour map, residual aeromagnetic intensity map, magnetic lineament map of the study area was obtained. Visual inspection of total aeromagnetic intensity contour map and the residual aeromagnetic intensity contour map of the study area revealed variations in magnetic field intensity throughout the area. Magnetic field intensity usually increases from the south towards the northern part of the area. The basement of the area is segment by faults oriented along different directions. The major faults were oriented along NE -SW, WNW -ESE, WNE-SSW directions while the minor faults were oriented along NW - SE, N-S directions.

\section{Reference}

[1]. Ajakaiye, D.E. (1974). Gravity survey over the Nigerian younger granite province in Kogbe, C.A. (Ed) geology of Nigeria .Elizabeth publishing co.Pp245 -253.

[2]. Ajakaiye, D.E., Hall, D.H. and Miller, T.W. (1983) Interpretation of Aeromagnetic data across the central crystalline shield areas of Nigeria. Geophysics Research journal, $81-90$

[3]. Ajakaiye, D.E., Hall, D.H., Miller, T.W.,Verheigen, P. (1986). Magnetic Anomaly and Tectonic trend in and around the Benue Trough, Nature 319: $582-584$

[4]. Aldana, M. and Costanzo - Alvarez, V. (2003). Magnetic and mineralogical studies to characterize oil reservoirs in Venezuela.The lead Edge22(6) Pp 526.

[5]. Anudu,G. K.,Stephenson, R.A. and David, I.M.(2014).Using high resolution Aeromagneticdata to recognized map intra- sedimentary Volcanic rocks and geological Structures acrossCretaceous middle Benue trough, Nigeria.Journal of African Earth Sciences 16 (1): 1-12

[6]. Conford, C. (1990). Source rocks and hydrocarbons of the North Sea in Glennie, K.W. (Ed) petroleum Geology of the North Sea. Basic concepts Recent advances. Blackwell Science, oxford, Pp 376 - 462

[7]. Costanzo - Alvaraz,V., Aldana, M., Aristeguica, O., Marcano, M.C. and Aconcha, E.E. (2000). Study of magnetic contrasts in the Guafita oil field (south - western Venezuela). Solid Earth Geodesy,25(5): 437 - 445.

[8]. Dow, W.G.(1978) Petroleum source beds on continental slopes and rise (2) American Association of Petroleum Geologists (AAPG).Bulleting vol.62.

[9]. Falconer, J. D. (1911).The Geology and Geography of Northern Nigeria. London: MacMillan.

[10]. GETECH Group Plc. (2007).Advanced processing and interpretation of gravity magnetic data. GETECH (Geophysical Exploration and Technology) Group Plc.Kitson house Elmete hall leeds, UK 22p

[11]. Gluyas, J. and Swarbick, R. (2005).Petroleum Geosciences. Blackwell science, oxford; 358Pp

[12]. Gunn, P.J., 1997. Application of aeromagnetic surveys to sedimentary Basin studies Australian Geological Society Organisation (AGSO). Journal of Australian Geophysics.17(2).Pp133-144.

[13]. Jacobson, R.R.E., Macleod, MW. andBlack,R.(1958). Ring complexes of younger granite province of northern Nigeria.Geological society of London memoir No.172

[14]. Keary, P., Brooks, S.M. and Hills, I. (2002).An introduction to geophysics Exploration. Third Edition . Blackwell Scientific Publisher, Oxford, 2.62Pp

[15]. Olasehinde, P.I., Pal, P.C. and Annor, A.E.(1990). Aeromagnetic Anomalies and structural lineaments in the Nigeria Basemen complex.Journal of African Earth sciences11(314).351 - 355

[16]. Oyowaye M.O. (1964) The geology of the Nigerian basement complex. Journal of Nigeria mining geology and metallurgical society.1 (2): Pp87-103.

[17]. Onyedim, G.C., Alagoa, K.D.,Adedekun, I.O., Aderogba, A.A.andOvuru, C.(2009).Mapping high- angle basementfaults in the Middle Benue Trough,Nigeria from Gravityinversion surfac, Journal of Earth Sceinces Research Vol.13: 2.Pp 140-147.

[18]. Peterson, N.R., and Reeves, C.V., (1985).Application of gravity and magnetic surveys; the state - of - the art in1985 Geophysics. 50.2558 2594.

[19]. Udensi, E. E., Osazuwa I. B. and Daniyan, M. A. (2003). Trend analysis of the total magnetic field over the Bida Basin, Nigeria.Nigerian Journal of Physics.15:143-151. 